\title{
TEMNOSPONDYL REMAINS FROM THE LATE PERMIAN RIO DO RASTO FORMATION (PARANÁ BASIN) OF BRAZIL
}

\author{
BRUNO DIAS RAMOS \\ Rua Saldanha da Gama, 170,Centro, 80060-170,Curitiba, PR, Brasil.bruno_d_ramos@yahoo.com.br \\ CRISTINA SILVEIRA VEGA \\ Departamento de Geologia, Centro Politécnico, UFPR, Cx.P. 19001, 81531-980, Curitiba, PR, Brasil. cvega@ufpr.br
}

\begin{abstract}
Several fragmentary and isolated materials are described from the Morro Pelado Member of the Late Permian Rio do Rasto Formation, that were found at PR-090, near São Jerônimo da Serra town (Paraná State). The materials consist of three mandibular fragments, six vertebral elements, a rib fragment, an interclavicle, a fragment of a probable scapulocoracoid and isolated proximal ends of an ulna and a femur. All the materials come from the same outcrop and the same fossiliferous horizon, without any indication of having belonged to the same individual. Although the anatomical features of most of the materials suggest they could be related to temnospondyl amphibians, their fragmentary nature and the absence of cranial specimens does not allow a more precise taxonomic identification. However, as fossil tetrapods are useful for biostratigraphic purposes, specially for the Permian-Triassic interval, the new discoveries in the Rio do Rasto Formation could provide additional support for a correlation of Permian sediments of Paraná Basin with the Pristerognathus, Tropidostoma and Cistecephalus Assemblage Zones of the Karoo Basin as previous studies have suggested. Although, new material and a more precise taxonomic identification could corroborate this correlation.
\end{abstract}

Key words: biostratigraphy, Late Permian, Rio do Rasto Formation, Temnospondyli.

RESUMO - Diversos materiais fragmentados e isolados são descritos provenientes do Membro Morro Pelado do Permiano Superior da Formação Rio do Rasto, encontrados na PR-090, próximo à cidade de São Jerônimo da Serra (Estado do Paraná). Os materiais consistem de três fragmentos mandibulares, seis elementos vertebrais, um fragmento de costela, uma interclavícula, o fragmento de um provável escápulo-coracoide, e fragmentos das porções proximais de uma ulna e de um fêmur. Todos os materiais foram coletados no mesmo afloramento e no mesmo horizonte fossilífero, sem sinal de terem pertencido ao mesmo indivíduo. Apesar das características anatômicas da maior parte dos materiais sugerirem que possam estar relacionadas a anfíbios temnospôndilos, sua natureza fragmentada e a ausência de espécimes cranianos não permite uma identificação taxonômica mais precisa. Entretanto, como tetrápodes fósseis são muito úteis para propósitos bioestratigráficos, especialmente para o intervalo Permiano-Triássico, as novas descobertas na Formação Rio do Rasto podem fornecer suportes adicionais para a correlação dos sedimentos permianos da bacia do Paraná com as zonas de assembleia de Pristerognathus, Tropidostoma e Cistecephalus da bacia de Karoo, como havia sido sugerido em estudos anteriores. Entretanto, novos materiais e também uma identificação taxonômica mais precisa poderá corroborar essa correlação.

Palavras-chave: bioestratigrafia, Permiano Superior, Formação Rio do Rasto, Temnospondyli.

\section{INTRODUCTION}

The Rio do Rasto Formation is part of the Passa Dois Group within the Paraná Basin infilling. According to Milani et al. (2007), the formation integrates the Gondwana I Supersequence of the basin, and is dated as Late Permian, showing different colors of clastic sediments. The Late Permian age of the formation is also corroborated by several biostratigraphic studies (Northfleet et al., 1969; Barberena \& Daemon, 1974; Barberena et al., 1980, 1985a,b, 1991; CazzuloKlepzig \& Correia, 1981). Others studies attribute a Middle/Late Permian (Cisneros et al., 2005; Ventura-Santos et al., 2006; Langer et al., 2008), or even totally Middle Permian age (Langer, 2000; Lucas, 2004) to the Rio do Rasto Formation. The main materials used for these correlations are the continental tetrapod fossils. The formation is divided in two members, the lower Serrinha
Member characterized by greenish siltstones and thin sandstones, and the upper Morro Pelado Member which consists of red claystones and siltstones with lenticular intercalations of thin sandstones (Schneider et al., 1974).

The Rio do Rasto Formation fossil record is very extensive. Conchostraceans, ostracods, molluscs (bivalves and gastropods), plants, and nodular stromatolites are present, as well as several vertebrates like temnospondyl amphibians (Barberena \& Daemon, 1974; Barberena, 1998; Barberena \& Dias, 1998; Dias \& Barberena, 2001; Dias \& Schultz, 2003; Malabarba et al., 2003; Vega \& Ramos, 2008; Ramos \& Vega, 2009; Ramos, 2009; Eltink \& Langer, 2008, 2010), the dicynodont Endothiodon (Barberena \& Araújo, 1975), dinocephalians (Langer, 1998, 2000), pareiasaurs (Araújo, 1985a,b; Lee, 1997a,b; Malabarba et al., 2003; Cisneros et al., 2005), xenacanthids (Ragonha, 1989), hybodontids (Richter \& Langer, 1998; Malabarba et al., 2003) 
and cladodontid sharks (Laurini et al., 2009), actinopterygian paleoniscids and dipnoan fishes (Ragonha, 1989; Dias, 1995; Vega-Dias et al., 2000), and in addition to these there are lepidosaurian and cynodontian tracks (Leonardi et al., 2002).

From the three recognized faunas containing tetrapods in the Rio do Rasto Formation (Cisneros et al., 2005), only the fauna known as Serra do Cadeado is located in the Paraná State. The other two faunas, Bagé-Aceguá and Posto Queimado are restricted to Rio Grande do Sul State.

The present work describes new tetrapod remains from the Rio do Rasto Formation, more precisely from a locality situated in the highway PR-090, São Jerônimo da Serra Municipality, where the upper part of that formation (the Morro Pelado Member) is represented. Tetrapod tracks attributed to Rhynchosauroides sp. (Lepidosauria) and Dicynodontipus (Cynodontia) have already been recorded from this outcrop (Leonardi et al., 2002).

The material consists of mandibular fragments and several postcranial elements, all of which come from the same fossiliferous horizon. Notwithstanding, all the pieces were found isolated and there is no evidence to suggest that they belonged to the same individual. The materials are deposited in the Laboratory of Fossil Preparation, at the Geology Department of the Universidade Federal do Paraná. The systematic follows Dias \& Schultz (2003). Institutional abbreviations. UFPR, Universidade Federal do Paraná; PV, Paleontologia de Vertebrados. Anatomical abbreviations. D, dentary; diap., diapophysis; gl.f., glenoid foramen; in.tr., internal trochanter; l.i.t., lateral interclavicular trabecula; m.sy., mandibular symphysis; na.f., neural arch facet; n.sp., neural spine; ol.p., olecranon process; parap., parapophysis; pl.f., pleurocentral facet; po.z., postzygapophysis; pr.z., prezygapophysis; s.i.t., sternal interclavicular trabecula; tri.m., attachment area for triceps muscle.

\section{SYSTEMATIC PALEONTOLOGY}

\section{AMPHIBIA Linnaeus, 1758 [sensu Gauthier et al., 1988] TEMNOSPONDYLIZittel, 1890 [sensu Milner, 1993]} (Figures 1-9; Table 1)

Material. Three mandibular fragments (UFPR 0097 PV, UFPR 0100 PV, UFPR 0099 PV), six vertebral elements (two neural archs, UFPR 0104 PV, UFPR 0105 PV; two pleurocentra, UFPR 0110 PV, UFPR 0117 PV; two intercentra, UFPR 0108 PV, UFPR 0109 PV), a rib fragment (UFPR 0107 PV), an interclavicle (UFPR 0098 PV), a probable scapulocoracoid (UFPR 0093 PV), a proximal ulna fragment (UFPR 0106 PV) and a proximal femur fragment (UFPR 0092 PV).

Horizon and locality. Morro Pelado Member, Rio do Rasto Formation, Wuchiapingian (Cisneros et al., 2005) or Capitanian (Langer et al., 2008). São Jerônimo da Serra Municipality

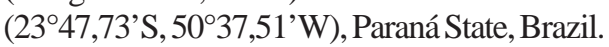

Age. Late Permian.

Description. Mandibles: the material UFPR 0097 PV consists on an anterior portion of a mandible, presenting a slight curvature in the distal region (Figure 1A). In ventral view, the proximal region displays the dermal ornamentation characteristic of temnospondyls amphibians (Figure 1B). This ornamentation probably extended to the distal portion of the bone, but the fragility of the material precludes a better preparation of that region.
The dentary is the only bone that can be identified in this fragment and it is exposed in both lingual and lateral views. Normally, the dentary is the largest bone in the temnospondyl mandible. The space for the Meckelian cartilages is not observed in the preserved fragment and its absence suggests that the mandible should be more elongated.

In lingual view, it is possible to observe a slight enlargement in the distal end of the bone, which represents the mandibular symphysis, which retains a single preserved tooth (Figure 1C). This is the only tooth observed in the whole surface of this mandible, although it is incomplete. Near the symphyseal region, a torsion of the bone can be observed. This is attributed to taphonomic processes.

The other two mandibular fragments are relatively smaller and less well preserved. UFPR $0100 \mathrm{PV}$ represents a fragment of the dentary (Figures 2A,B). In ventral view, the dermal ornamentation is well preserved. Lingually, it is possible to observe the basal portions of six sectioned teeth, which are preserved in sequence, forming a row of teeth. The poor preservation state of these teeth does not allow a detailed description of them. Another characteristic observed in dorsal view, but more evident in transversal section, is the presence of an elevation in the central portion of the bone, which may correspond to a bar-like structure (Dias \& Barberena, 2001) visible next to the teeth row.

UFPR $0099 \mathrm{PV}$ is a relatively smaller fragment and is poorly preserved. It is not possible to be precise as to which bones are present in this sample (Figures 2C,D). In ventral view, the dermal ornamentation is visible although poorly preserved. From the lingual view, the specimen seems to represent the central portion of the mandible, the two rows of teeth that would be found on the sides of the sample being absent. Also in lingual view there can be seen a small elevation over almost all of the central surface of the bone, which is believed to correspond to a part of the barlike structure (Dias \& Schultz, 2003).

Vertebral elements: all the vertebral elements are from rhachitomous vertebrae, and were found close to each other, although disarticulated. They consist of two neural archs and four centra (two pleurocentra and two intercentra).

UFPR 0104 PV consists of a neural spine, rectangular in shape, and straight-sided, measuring approximately $40 \mathrm{~mm}$ in height, and about $17 \mathrm{~mm}$ deep (medio-laterally). It is connected to the left transverse process. This process measures approximately $13 \mathrm{~mm}$ dorso-ventrally and $22 \mathrm{~mm}$ mediolaterally (Figure 3A). The total measurements of this neural arch are presented in Table 1. In posterior view, the transverse process displays the pleurocentral facet in its middle region, occupying about $2 / 3$ of the process, and the diapophysis is in its distal end (Figure 3B). UFPR 0105 PV corresponds only to a neural spine, which is larger than UFPR 0104 PV (see Table 1) (Figures 3C,D).

Anteriorly and posteriorly both neural spines preserve the pre- and postzygapophysis respectively. Due to a relative degree of compression observed in both neural archs, the measurements presented in the text and in the Table 1 may not correspond to their real size in life. In UFPR 0104 PV, the prezygapophysis measures about $0.5 \mathrm{~mm}$ dorso-ventrally and $0.7 \mathrm{~mm}$ mediolaterally; they are slightly tilted, with their inclination following the anterior surface of the neural spine. The postzygapophysis 


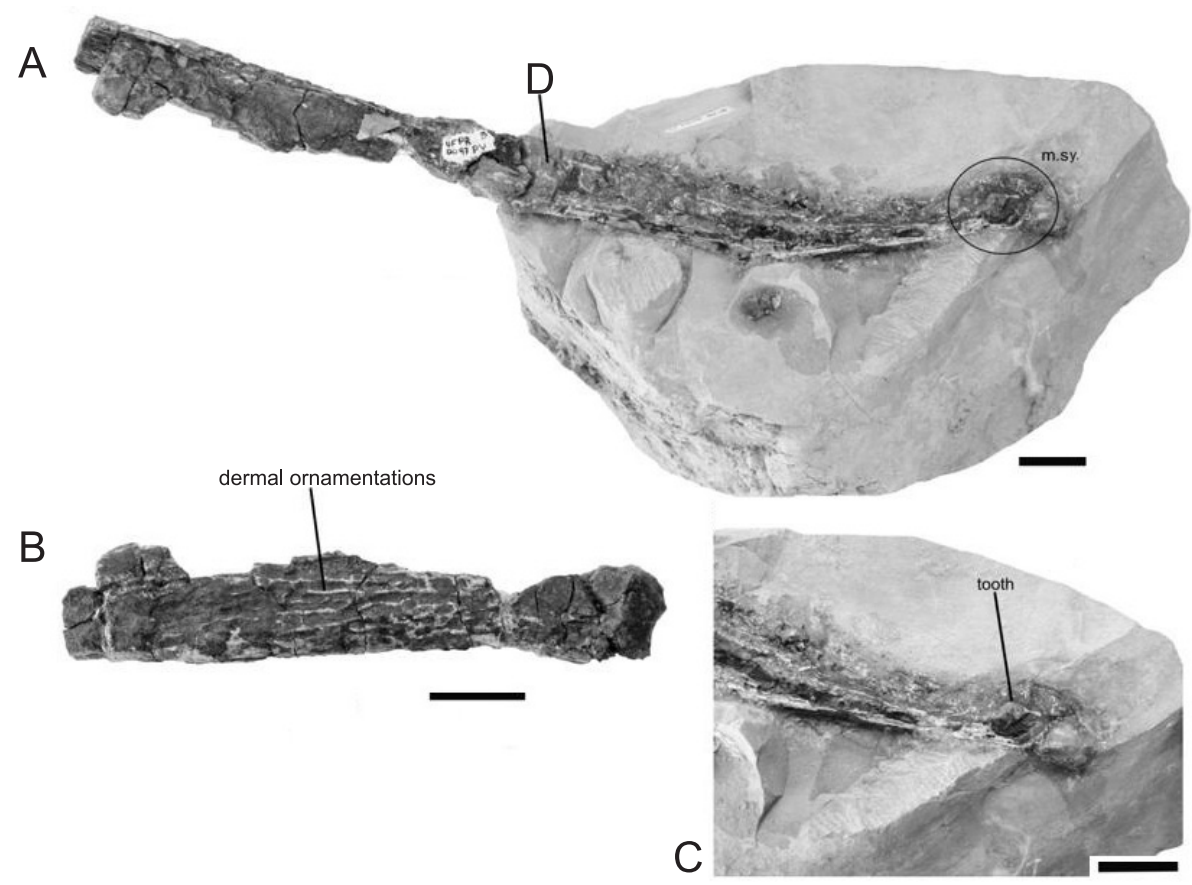

Figure 1. UFPR 0097 PV. A, mandible fragment, ventral view; B, proximal end, lateral view; C, distal end, ventral view. See text for abbreviations. Scale bars: $A, B=20 \mathrm{~mm}$; $C=10 \mathrm{~mm}$.

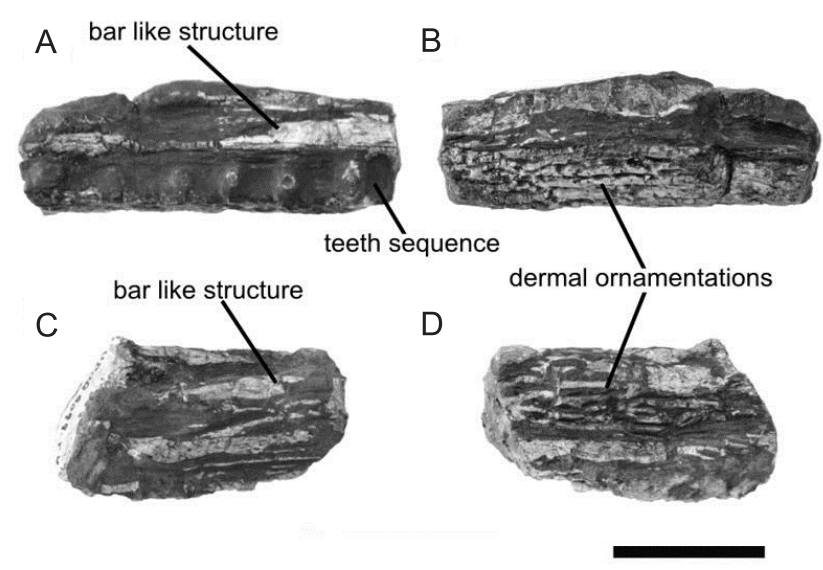

Figure 2. Mandible fragments. A, B, UFPR 0100 PV, lingual and ventral views, respectively; C, D, UFPR 0099 PV, lingual and ventral views, respectively. See text for abbreviations. Scale bar $=20 \mathrm{~mm}$.

are about $45^{\circ}$ dorso-ventrally tilted and measure about $0.7 \mathrm{~mm}$ dorso-ventrally and $1 \mathrm{~mm}$ medio-laterally.

The fossa for the inter-vertebral ligament is also observed, just above the pre- and postzygapophysis. In UFPR 0104 PV, the anterior fossa is larger but shallower than the posterior, as also occurs in UFPR 0105 PV. In UFPR 0104 PV the anterior fossa measures about $11 \mathrm{~mm}$ high and $3 \mathrm{~mm}$ wide at the thickest point, and the posterior fossa is about $9 \mathrm{~mm}$ high and $6 \mathrm{~mm}$ wide. In the sample UFPR 0105 PV, the anterior fossa measures approximately $14 \mathrm{~mm}$ high and $3 \mathrm{~mm}$ wide at the thickest point, and the posterior fossa is about $9 \mathrm{~mm}$ high and $4 \mathrm{~mm}$ wide. Notwithstanding, due to a certain degree of compression, these dimensions probably do not represent the real measurements observed in life. On both sides, the neural spines display lateral ridges, for muscle insertions.

The two pleurocentra do not present many diagnostic features. The smallest (UFPR 0110 PV) has a wedge-shape, with a little curvature in its dorso-ventral length (Figure 4A).
The bigger (UFPR $0117 \mathrm{PV}$ ) is also wedge-shaped but straight (Figure 4B). In both pleurocentra the neural facet, which connects the pleurocentrum with the transverse process of the neural arch, is visible in both lateral and anterior views.

The intercentra have different dimensions (Table 1). UFPR 0109 PV (Figure 4C,D) is bigger and shows only its right side end preserved. It is possible that the left end was fragmented during taphonomic processes. UFPR $0108 \mathrm{PV}$, the smaller intercentrum, is completely preserved (Figure 4E,G). Both intercentra are crescent-shaped in anterior and posterior views (a feature which is common in rhachitomous format), with the base wider than the dorsal portion and with the lateral and ventral sides slightly concave. The parapophysis are present in both specimens. In UFPR 0109 PV this structure is observed in the left side, occupying about 1/3 of the surface. In UFPR 0108 $\mathrm{PV}$, the same structure is present in both ends, occupying approximately $1 / 2$ of the side of the bone.

The shape and arrangement of the vertebral centrum elements (pleurocentra and intercentra) indicate these are rhachitomous. In this type of vertebra, the centrum presents a low degree of ossification as pleurocentra and intercentra are separate elements, not forming complete rings. They are distinct bony elements held in position by the presence of cartilage surrounding them (Dias \& Schultz, 2003; Pawley, 2006).

Rib: the material UFPR 0107 PV consists of a distal fragment of a right trunk rib (Figure 5). It is a slender bone fragment, which presents as its most characteristic feature, the presence of a thin keel shaped structure, in its most distal portion, which corresponds to the uncinate process. This process runs for more than a half of the total length of the preserved rib.

Interclavicle: UFPR $0098 \mathrm{PV}$ is a relatively large and flat diamond-shaped bone (Figure 6; Table 1). Although not completely preserved, it is observed that the anterior extremity is more elongated than the others. The fragility of the material precludes further preparation on it to allow exposure of the 
ventral region. Therefore, the material is described by the characteristics visible in dorsal view.

On the interclavicle it is possible to visualize three broad ridges, which correspond to lateral and sternal trabeculae. The lateral trabeculae emerge from the side edges of the bone, in the region of its maximum width, and are directed inwards towards the center of the bone, being slightly displaced down, where they meet the sternal trabecula. This trabecula leaves the posterior distal region of the bone, and is also directed to the center of the bone. The region where the three trabeculae come together corresponds to the ossification center.

Scapulocoracoid: UFPR 0093 PV is not well preserved, and a few portions were lost during collecting. The bone is relatively thin, with $5 \mathrm{~mm}$ in its thicker region, and only the lateral surface is visible. The exposed region corresponds to a lateral view of the bone (Figure 7). Although the material shows few diagnostic features, a comparison with temnospondyl postcranial material allowed a tentative identification of this material as part of a scapulocoracoid.

It is possible to observe a single foramen found next to a ridge, which could be one of the scapular ridges. The lateral

Table 1. Table of measurements.

\begin{tabular}{ccccc}
\hline Bone & Sample number & $\begin{array}{c}\text { Length } \\
(\mathrm{mm})\end{array}$ & $\begin{array}{c}\text { Width } \\
(\mathrm{mm})\end{array}$ & $\begin{array}{c}\text { Height } \\
(\mathrm{mm})\end{array}$ \\
\hline $\begin{array}{c}\text { Mandibular } \\
\text { fragments }\end{array}$ & UFPR 0097 PV & 275 & 25 & 08 \\
& UFPR 0099 PV & 37 & 22 & 12 \\
& UFPR 0100 PV & 50 & 18 & 12 \\
Vertebral & UFPR 0104 PV & 17 & 33 & 50 \\
elements & UFPR 0105 PV & 19 & 08 & 40 \\
& UFPR 0108 PV & 15 & 25 & 16 \\
& UFPR 0109PV & 17 & 26 & 19 \\
& UFPR 0110 PV & 09 & 11 & 19 \\
& UFPR 0117 PV & 09 & 12 & 24 \\
Rib & UFPR 0107 PV & 25 & - & 52 \\
Interclavicule & UFPR 0098 PV & 110 & 97 & 05 \\
Scapulocoracoid & UFPR 0093 PV & - & - & 35 \\
Ulna & UFPR 0106PV & 16 & 22 & 31 \\
Femur & UFPR 0092 PV & 11 & 25 & 27 \\
\hline
\end{tabular}

edge of the bone located on the right side of the scapular ridge is curved and it is possible to see that the two ends of this edge would have been prolonged in the original bone. It seems that the foramen passes right through the scapulocoracoid and opens onto the outer portion of the bone, and therefore may correspond to the coracoid or glenoid foramen (see discussion below), but the designation of this structure as one of these foramen should be made with caution. Moreover, the absence of the glenoid cavity does not allow a conclusive identification of the material.

Ulna: the material UFPR 0106 PV consists of a fragment from the proximal portion of a left ulna (Figure 8; Table 1). It is possible to observe the olecranon process in anterior and posterior views, as well as a roughness on its surface, which corresponds to the attachment area for the triceps muscle. These characteristics have been described by Pawley (2006) for Trimerorhachis insignis. There was also observed, in posterior view, a crest, interpreted as being the posterior ulnar crest.

Femur: UFPR 0092 PV consists of a fragment from the proximal portion of a right femur (Figure 9; Table 1). Despite this being a relatively small fragment, it is possible to observe the internal trochanter and the intertrochanteric fossa in ventral view. The internal trochanter is developed along the side of the preserved bone, being fragmented only on its most proximal portion, probably a result of the taphonomic process. The intertrochanteric fossa, in turn, is a small concavity, presenting about $2 \mathrm{~mm}$ of depth. No diagnostic feature is visible in anterior view.

Comparisons. Mandibles: in relation to UFPR 0097 PV, the elongated shape of the dentary and its slight curvature, as well as the presence of a possible symphyseal tooth, allow us to assign the sample to a long snouted temnospondyl amphibian. The only long snouted temnospondyl amphibian recorded in the Serra do Cadeado Fauna until now is Australerpeton cosgriffi (Barberena, 1998; Dias \& Schultz, 2003). So far, no Australerpeton cosgriffi mandible has been formally described, although, mandibular material attributed to Australerpeton cosgriffi has been documented (Eltink \& Langer, 2008). UFPR 0097PV was compared with Australerpeton only by the similarities it shares with the cranium of Australerpeton cosgriffi, like the elongated size, the symphysis position, and from the fact that this is the only longsnouted temnospondyl known from the Rio do Rasto Formation in Paraná State outcrops. The preservation state of this jaw fragment does not allow a comparison with the already known mandible of Bageherpeton longignathus Dias \& Barberena,

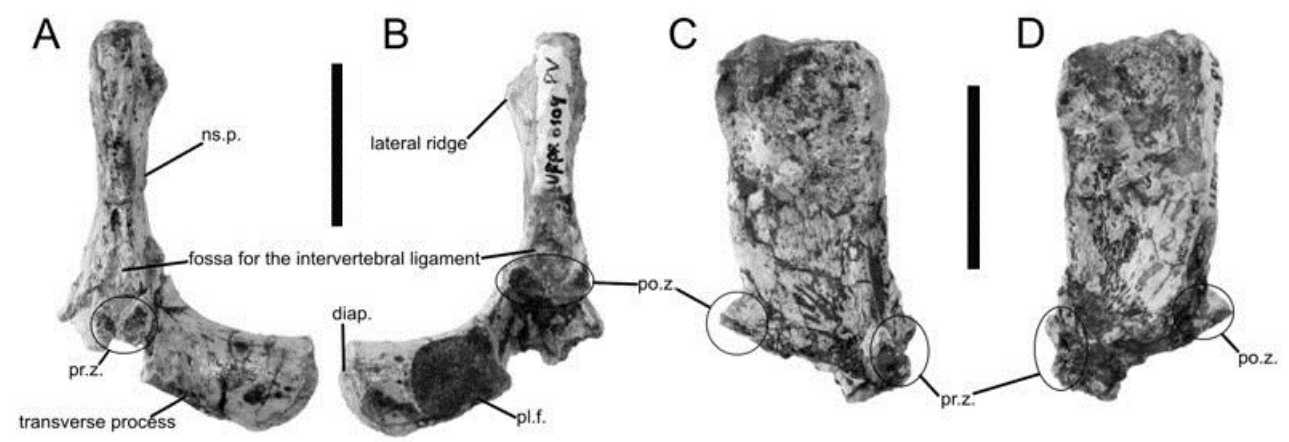

Figure 3. Neural arch elements. A, B, UFPR 0104 PV, neural spine and left transverse process, anterior and posterior views, respectively; C, D, UFPR 0105 PV, neural spine, right and left views, respectively. See text for abbreviations. Scale bars $=20 \mathrm{~mm}$. 
2001, another long-snouted temnospondyl described from the Rio do Rasto Formation. The lack of structures, which were well observed and described in Bageherpeton longignathus, such as the Meckelian cavity and the bar-like structure, as well as its fragmentary state, does not allow such comparison.

The presence of a bar-like structure in both small samples (UFPR 0099 PV and UFPR 0100 PV) is questionable. An elevation in the central portion of both samples is observed, and could indicate the presence of such a structure, but it is not possible to be certain of this. Seeing that both the long-snouted temnospondyl taxa from the Rio do Rasto Formation, Australerpeton and Bageherpeton, are apparently aquatic predators (Dias \& Barberena, 2001; Dias \& Schultz, 2003), the presence of a bar-like structure could represent an adaptation to this diet. Dias \& Barberena (2001), describing the Bageherpeton longignathus mandible, suggested that the function of this barlike structure was to strengthen the elongated mandibular symphyseal region.

Vertebral elements: concerning the vertebral elements, the rectangular shape in lateral view of both neural spines described matches with what was described by Dias \& Schultz (2003) for Australerpeton, as well as cited by Pawley (2006) for other basal temnospondyls, such as Trimerorhachis insignis Cope, 1878 and Eryops megacephalus Cope, 1877. According to Dias \& Schultz (2003), the pleurocentral facet and diapophysis positions in the preserved transverse process are similar to those observed in Australerpeton cosgriffi Barberena, 1998 and in other temnospondyls, as also stated by Pawley (2006). The wedge shape observed in both pleurocentra is a feature already described by Dias \& Schultz (2003) for Australerpeton cosgriffi. The differences in size observed on the described pleurocentra suggest different ages for the specimens, or they could also represent elements from different regions of the body. The neural arch facet is observed in practically the same position in both specimens (UFPR 110 PV and UFPR 0117 PV), and is fairly similar to that described by Pawley (2006) for all temnospondyl amphibians. The shape of the intercentrum is identical to that observed in Australerpeton (Dias \& Schultz, 2003). The parapophysis at the sides of both intercentra matches that observed in several temnospondyl amphibians (Pawley, 2006) and also in Australerpeton cosgriffi (according to Dias \& Schultz, 2003).

Rib: according to Pawley (2006), the uncinate process is found in the first trunk ribs in several temnospondyl amphibians, being unknown in basal temnospondyls, but is present in basal stereospondyl groups such as the Lydekkerinidae and the Rhinesuchidae to which Australerpeton cosgriffi may belong (Barberena et al., 1985 a and b; Barberena, 1998; Barberena \& Dias 1998; Dias \& Schultz, 2003). Witzmann \& Schoch (2006) consider Australerpeton a transitional basal temnospondyl related to Archegosaurus and Stereospondyli. Anyway, we must consider that our material is found disarticulated, and the bones
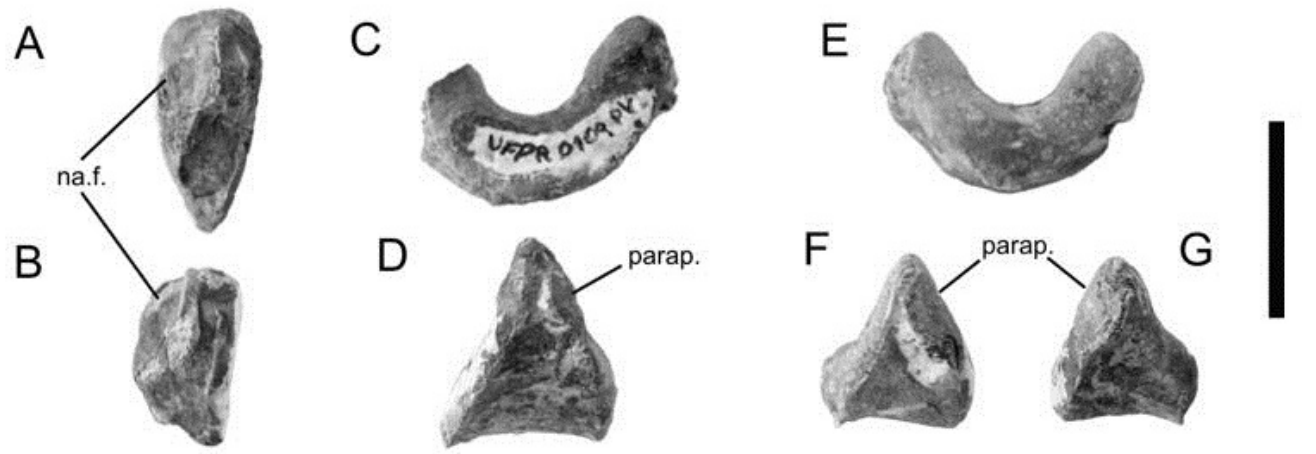

Figure 4. Neural center elements. A, Pleurocentrum UFPR 0117 PV, anterior view. B, Pleurocentrum UFPR 0110 PV, anterior view. C, D, Intercentrum UFPR 0109 PV, anterior view and left side, respectively. E-G, Intercentrum UFPR 0108 PV, anterior view, left and right side, respectively. See text for abbreviations. Scale bars $=20 \mathrm{~mm}$.

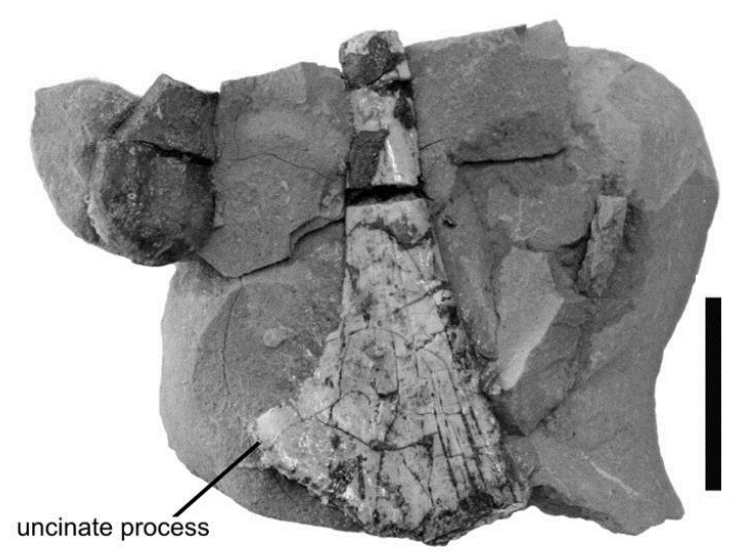

Figure 5. UFPR $0107 \mathrm{PV}$, distal fragment of a right rib, internal view. Scale bar $=20 \mathrm{~mm}$.

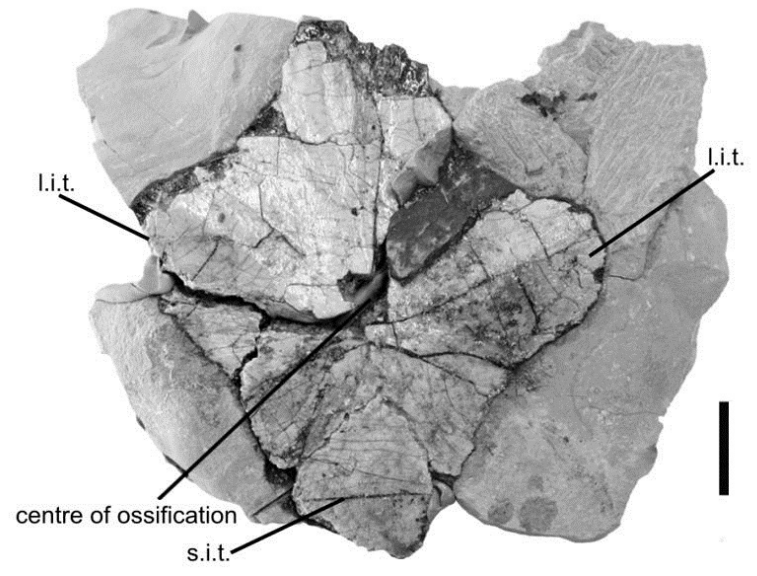

Figure 6. UFPR $0098 \mathrm{PV}$, interclavicle, dorsal view. See text for abbreviations. Scale bar $=20 \mathrm{~mm}$. 
could not pertain to the same individual and could correspond to a distinct taxa. Dias \& Schultz (2003) characterized the ribs of Australerpeton cosgriffi, indicating that the uncinate process is found in different positions within the trunk ribs. In the anterior trunk ribs this structure is placed more medially in the bone, but becomes more distally placed posteriorly.

Interclavicle: although not totally preserved, UFPR 0098 $\mathrm{PV}$ is morphologically similar to the interclavicle of Mastodonsaurus giganteus Jaeger, 1828, a temnospondyl from the Middle Triassic of Germany (Schoch, 1999) and the position of its trabeculae is identical to that observed in Benthosuchus sushkini Bystrow \& Efremov, 1940, from the Early Triassic of Russia (Pawley, 2006). The Australerpeton cosgriffi interclavicle (Dias \& Schultz, 2003) is described only in ventral view, which prevents at the moment any comparison with the sample described here. However, the format of UFPR 0098 PV appears to be somewhat different from the interclavicle of Australerpeton cosgriffi, since on this last species the interclavicle is oval shaped. Dias \& Schultz (2003) described a rounded and short posterior margin to Australerpeton cosgriffi interclavicles, with the anterior portion of the interclavicles corresponding to two thirds of the bone. Although the posterior margin of UFPR $0098 \mathrm{PV}$ is not completelly preserved, it is possible to observe the absence of a rounded format, since we have a thick broken bone that is thinner than the body of the bone. This is a character distinct from

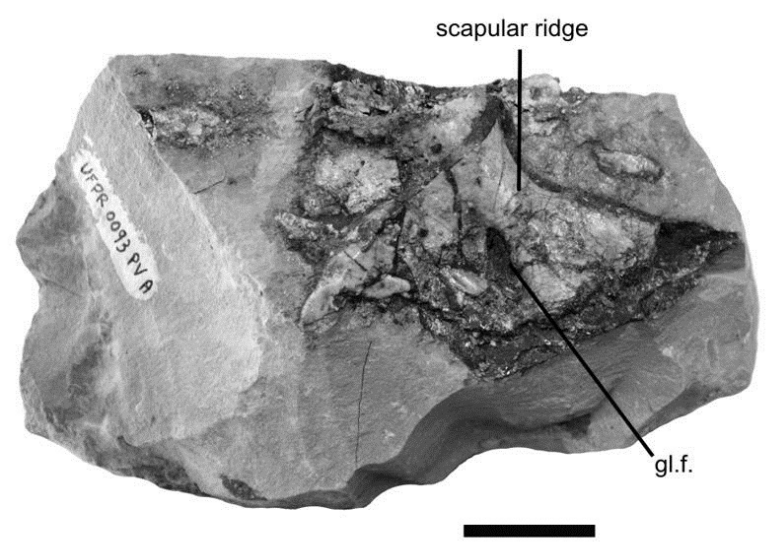

Figure 7. UFPR 0093 PV, lateral view of the scapulocoracoid. See text for abbreviations. Scale bar $=20 \mathrm{~mm}$.

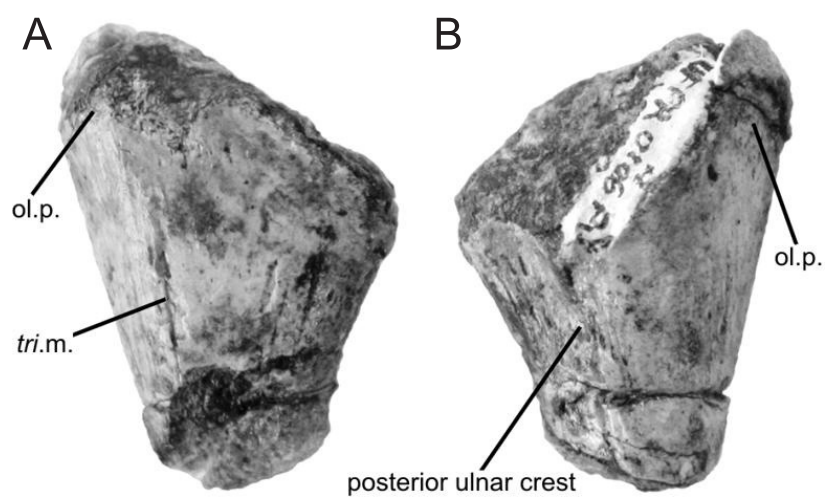

Figure 8. UFPR $0106 \mathrm{PV}$, proximal fragment of a left ulna. A, anterior view; B, posterior view. See text for abbreviations. Scale bar $=20 \mathrm{~mm}$.
Australerpeton cosgriffi, since in this species the posterior margin of interclavicle is very short and rounded. In UFPR 0098 $\mathrm{PV}$, the lateral trabecules are very pronounced, while this feature is not so evident in Australerpeton cosgriffi. On this last species, the lateral trabecules do not extend through the lateral margin. Considering the anterior portion of UFPR 0098 PV interclavicle, although not completely preserved, it is possible to visualize that this portion is very elongated, thinner than the entire bone. In Australerpeton cosgriffi, this anterior portion is shorter and less pronounced, accompanying the entire body of bone.

Scapulocoracoid: the identification of the material UFPR $0093 \mathrm{PV}$ as a scapulocoracoid is mainly due to the presence of the foramen interpreted tentatively as the coracoid or glenoid foramina. Dias \& Schultz (2003) observing the Australerpeton cosgriffi scapulocoracoid, interpreted two foramina observed next to the glenoid cavity as the supracoracoid and coracoid foramina. However, both foramina are synonymous, and maybe they are distict foramina on this species. In Eryops megacephalus, in the same region, three foramina are visible (Pawley, 2006): the coracoid, glenoid and supraglenoid foramen. The supraglenoid foramen is located in the middle of the deep supraglenoid fossa; the ventrally located glenoid and coracoid foramen are located on the coracoid. The foramen observed on UFPR 0093 PV could be the coracoid or glenoid foramen, since the glenoid cavity, where the supraglenoid foramen is expected, is not preserved.

Femur: the structures observed in the femur UFPR 0092 $\mathrm{PV}$, the internal trochanter and the intertrochanteric fossa, are both visible in the proximal portion of temnospondyl femora (Dias \& Schultz, 2003; Pawley, 2006). Although in Australerpeton cosgriffi the femur has its original shape compressed due to taphonomic process (Dias \& Schultz, 2003), there is observed a high morphological similarity between UFPR 0092 PV and the femur described by Dias \& Schultz (2003), as well as with Trimerorhachis insignis femur (Pawley, 2006). UFPR 0092 PV shares with Australerpeton cosgriffi and Trimerorhachis insignis the presence of a distinct internal trochanter that runs through the body of the bone. The three specimens also share the outline of the proximal extremity of femura, as the internal trochanter projects "down and backward, with a slender portion between itself and the head of the femur" (Dias \& Schultz, 2003).
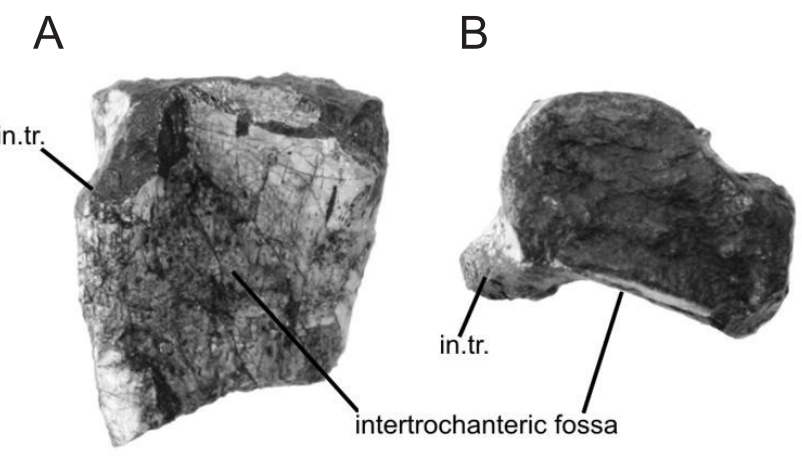

Figure 9. UFPR $0092 \mathrm{PV}$, proximal fragment of a right femur. A, posterior view; B, proximal view. See text for abbreviations. Scale bar $=20 \mathrm{~mm}$. 


\section{DISCUSSION}

Considering the stratigraphic distribution of temnospondyl taxa within the Rio do Rasto Formation, the archegosaurid Bageherpeton longignathus was only found in sediments that correspond to the Posto Queimado and Aceguá Faunas, in Rio Grande do Sul State, while Australerpeton cosgriffi is recorded in the Serra do Cadeado Fauna, Paraná State. According to Cisneros et al. (2005), the Posto Queimado and Aceguá Fauna is from Guadalupian (Capitanian age), and the Serra do Cadeado Fauna is attributed to Lopingian (Wuchiapingian age). Langer et al. (2008) on the other hand, suggest an older age for the Rio do Rasto Formation, placing both faunas in the Guadalupian, with a Wordian age for the Rio Grande do Sul State faunas, and a Capitanian age for the Paraná State fauna.

A contemporaneity between temnospondyl amphibians and the dicynodont Endothiodon is observed in the Serra do Cadeado Fauna, which is correlated with the Karoo Basin. In this African basin, the simultaneous occurrence of these two tetrapod groups is restricted to only three biostratigraphic zones: the Pristerognathus, Tropidostoma and Cistecephalus Assemblage Zones, all of them corresponding to sediments dated from Late Permian (Rubidge, 1995; Cisneros et al., 2005).

Cisneros et al. (2005), comparing pareiasaurs found in the Aceguá and Posto Queimado faunas, at the Rio Grande do Sul State, placed both these faunas in the base of the Rio do Rasto Formation. The presence of pareiasaurs associated with dinocephalians allows the correlation of these south Brazilian faunas with the Tapinocephalus Assemblage Zone, in the Karoo Basin, which is the only fauna where these two tetrapod groups are registered together.

The absence of cranial material associated with the postcranial materials described herein does not allow a more accurate identification for them. However, the analysis of the features and structure of the mandibular fragments, and of the postcranial material, allows the attribution of those fossils to temnospondyl amphibians. It is believed that they may correspond to specimens of the long-snouted genus Australerpeton, considering the similarities between the materials described and Australerpeton cosgriffi, and also because this species is the only long-snouted temnospondyl described in the Rio do Rasto Formation at the Paraná State until now. However, the material could correspond to distinct taxa of temnospondyl amphibians, even to distinct species. As said before, the absence of cranial materials, and also the fragmentary state of some bones presented here, does not allow a precise taxonomic classification of these materials. New field works could help in the characterization of these forms.

The taxonomic position of Australertepon cosgriffi is still not very well known, and several interpretations have been made. Studies which analyzed cranial and postcranial specimens place this species within the Rhinesuchidae (Barberena et al., 1985a,b; Barberena, 1998; Barberena \& Dias 1998; Dias \& Schultz, 2003). However, in their recent phylogenetic analysis of Temnospondyl postcrania, Witzmann \& Schoch (2006) placed the genus Australerpeton between Archegosaurus and the Stereospondyl, within the Stereospondylomorpha, but in a different branch of the rhinesuchids.

If it is considered that Australerpeton cosgriffii is a temnospondyl amphibian of the family Rhinesuchidae, and that it occurs, along with the dicynodont Endothiodon, within the Serra do Cadeado fauna, a fauna that has been associated with the Rio do Rasto Formation (Barberena \& Daemon, 1974; Barberena et al., 1985a,b, 1991; Langer, 2000; Cisneros et al., 2005; Langer et al., 2008), so then its possible presence in the materials described here, which were collected from an outcrop where the contact between the Rio do Rasto and the Piramboia formations are visible, would allow the correlation of the fauna found in the Paraná State with the Pristerognathus, Tropidostoma and Cistecephalus Assemblage Zone from Africa, and to be of Lopingian Epoch (Wuchiapingian age) according Cisneros et al. (2005) or Guadalupian Epoch (Capitanian age) according Langer et al. (2008).

If the assignation of the described materials to Australerpeton is correct, and can be confirmed by the finding of more complete specimens, a biostratigraphic correlation between the Rio do Rasto Formation and the Permian units of the South African Beaufort Group (Karoo Basin), could be better supported.

\section{ACKNOWLEDGMENTS}

The authors give thanks to the Conselho Nacional de Desenvolvimento Científico e Tecnológico (CNPq) and the Fundação Araucária for financial support; to the Laboratório de Análise de Bacias e Petrofísica (LABAP), UFPR, for help on fieldtrips in 2007 and 2009; to R. Silva, F. Chimentão and Museu de Ciências Naturais for help on the fieldtrip in 2007. Thanks to E.V. Dias and K.S. Jaworski, and also the reviewers, for suggestions. Thanks also to M.A.B. Souza for the photographs.

\section{REFERENCES}

Araújo, D.C.F. 1985a. Sobre Pareiasaurus americanus sp. nov., do Permiano Superior do Rio Grande do Sul, Brasil. I - Diagnose específica. Anais da Academia Brasileira de Ciências, 57:63-66.

Araújo, D.C.F. 1985b. Estudo do material sul-americano de Pareiasauroidea: II- Descrição osteológica do crânio de Pareiasaurus americanus. Anais da Academia Brasileira de Ciências, 57:67-85.

Barberena, M.C. 1998. Australerpeton cosgriffi n.g., n.sp., a Late Permian rhinesuchoid amphibian from Brazil. Anais da Academia Brasileira de Ciências, 70:125-137.

Barberena, M.C. \& Araújo, D.C. 1975. Tetrapodos fosiles de Sudamerica y deriva continental. In: CONGRESO ARGENTINO DE PALEONTOLOGÍA Y BIOESTRATIGRAFÍA, 1975. Actas, Tucumán, 1:497-504.

Barberena, M.C.; Araújo, D.C. \& Lavina, E.L. 1985a. Late Permian and Triassic tetrapods of the Southern Brazil. National Geografic Research, 1:5-20.

Barberena, M.C.; Araújo, D.C.; Lavina, E.L. \& Azevedo, S.K. 1985b. O estado atual de conhecimento sobre os tetrápodes permianos e triássicos do Brasil meridional. Brasília, Departamento Nacional da Produção Mineral, p. 21-28 (Série Geologia 27/Seção Paleontologia e Estratigrafia 2).

Barberena, M.C.; Araújo-Barberena, D.C.; Lavina, E.L. \& Faccini, U.F. 1991. The evidence for close paleofunistic affinity between South America and Africa, as indicated by Late Permian and Early Triassic Tetrapods. In: INTERNATIONAL GONDWANA SYMPOSIUM, 7, 1991. Proceedings, São Paulo, p. 455-467.

Barberena, M.C.; Correia, N.R. \& Aumond, J.J. 1980. Contribuição à estratigrafia e bioestratigrafia do Grupo Passa Dois na Serra do 
Cadeado (nordeste do Paraná, Brasil). Revista Brasileira de Geociências, 10:268-275.

Barberena, M.C. \& Daemon, R.F. 1974. A primeira ocorrência de Amphibia (Labyrinthodontia) na Formação Rio do Rasto, implicações geocronológicas e estratigráficas. In: CONGRESSO BRASILEIRO DE GEOLOGIA, 1974. Anais, Porto Alegre, SBG, 2:251-261.

Barberena, M.C. \& Dias, E.V. 1998. On the presence of a short-snouted rhinesuchoid amphibian in the Rio do Rasto Formation (Late Permian of Paraná Basin, Brazil). Anais da Academia Brasileira de Ciências, 70(3):465-468.

Cazzulo-Klepzig, M. \& Correia, N.R. 1981. Contribuição ao estudo da tafoflora permiana do Membro Serrinha na Serra do Cadeado, Estado do Paraná, Brasil. In: CONGRESSO LATINO-AMERICANO DE PALEONTOLOGIA, 2, 1981. Anais, Porto Alegre, p. 233-247.

Cisneros, J.C.; Abdala, F. \& Malabarba, M.C. 2005. Pareiasaurids from the Rio do Rasto Formation, Southern Brazil: biostratigraphic implications for Permian faunas of the Paraná Basin. Revista Brasileira de Paleontologia, 8(1):13-24.

Dias, E.V. 1995. Nova espécie de peixe (Actinopterygii, Platysomidae) do Permiano-Triássico da Bacia do Paraná, Brasil. Programa de Pós-Graduação em Geociências, Universidade Federal do Rio Grande do Sul, Dissertação de Mestrado, 88 p.

Dias, E.V. \& Barberena, M.C. 2001. A temnospondyl amphibian from the Rio do Rasto Formation, Upper Permian of Southern Brazil. Anais da Academia Brasileira de Ciências, 73(1):136-143.

Dias, E.V. \& Schultz, C.L. 2003. The first paleozoic temnospondyl postcranial skeleton from South America. Revista Brasileira de Paleontologia, 6:29-42.

Eltink, E. \& Langer, M.C. 2008. Novos espécimes de temnospôndilos da Serra do Cadeado (nordeste do Paraná). In: SIMPÓSIO BRASILEIRO DE PALEONTOLOGIADE VERTEBRADOS, 6, 2008. Boletim de Resumos, Ribeirão Preto, USP, 1:86-88.

Eltink, E. \& Langer, M.C. 2010. Sobre um espécime de anfíbio Temnospondyli procedente da Serra do Cadeado, Paraná. In: SIMPÓSIO BRASILEIRO DE PALEONTOLOGIA DE VERTEBRADOS, 7, 2010. Boletim de Resumos, Rio de Janeiro, UNIRIO/DNPM, 1:18.

Gauthier, J.A.; Kluge, A.G. \& Rowe, T. 1988. The early evolution of the Amniota. In: M.J. Benton (ed.) The phylogeny and classification of the tetrapods, volume 1, Amphibia, Reptiles, Birds, Systematics Association Special Volume, 35A:103-155.

Langer, M.C. 1998. Are the dinocephalians present in Brazil Upper Permian? Journal of African Earth Sciences, 27(1):129-130.

Langer, M.C. 2000. The first record of dinocephalians in South America: Late Permian (Rio do Rasto Formation) of the Paraná Basin, Brasil. Neues Jahrbuch für Geologie und Paläontologie, Abhandlungen, 215(1):69-95.

Langer, M.C.; Eltink, E.; Bittencour, J.S. \& Rohn, R. 2008. Serra do Cadeado, PR: uma janela paleobiológica para o Permiano continental sul-americano. In: M. Winge; C. Schobbenhaus; C.R.G. Souza; A.C.S. Fernandes; M. Berbert-Born \& E.T. Queiroz (eds.) Sítios Geológicos e Paleontológicos do Brasil. Available at http:// www.unb.br/ig/sigep/sitio007/sitio007.pdf; accessed on 04/08/2008.

Laurini, C.R.; Richter, M. \& Langer, M.C. 2009. Chondrichthyan teeth from the Rio do Rasto Formation, Permian of Brazil. Journal of Vertebrate Paleontology, 29:133A.

Lee, M.S.Y. 1997a. A taxonomic revision of pareiasaurian reptiles: implications for Permian terrestrial palaeoecology. Modern Geology, 21:231-289. doi: 10.1111/j.1096-3642.1997.tb01279.x

Lee, M.S.Y. 1997b. Pareiasaur phylogeny and the origin of turtles. Zoological Journal of the Linnean Society, 120:197-280.

Leonardi, G.; Sedor, F.A. \& Costa, R. 2002. Pegadas de répteis terrestres na Formação Rio do Rasto (Permiano Superior da Bacia do Paraná), Estado do Paraná, Brasil. Arquivos do Museu Nacional, 60(3):213-216.
Lucas, S.G. 2004. A global hiatus in the Middle Permian tetrapod fossil record. Stratigraphy, 1(1):47-64.

Malabarba, M.C.; Abdala, F.; Weiss, F. \& Perez, P.A. 2003. New data on the Late Permian vertebrate fauna of Posto Queimado, Rio do Rasto Formation, Southern Brazil. Revista Brasileira de Paleontologia, 6:49-54.

Milani, E.J.; De Melo, J.H.G.; De Souza, P.A.; Fernandes, L.A. \& França, A.B. 2007. Bacia do Paraná. Boletim de Geociências da Petrobras, 15(2):265-287.

Milner, A.R. 1993. Amphibian-Grade Tetrapoda. In: M.J. Benton (ed.) The Fossil Record 2, Chapman \& Hall, p. 663-677.

Northfleet, A.A.; Medeiros, R.A. \& Muhlmann, H. 1969. Revalidação dos dados geológicos da Bacia do Paraná. Boletim Técnico da Petrobras, 12(3):291-346.

Pawley, K. 2006. The postcranial skeleton of temnospondyls (Tetrapoda: Temnospondyli). Department of Zoology, La Trobe University, $\mathrm{PhD}$. Thesis, $470 \mathrm{p}$.

Ragonha, E.W. 1989. Placas dentárias de Dipnoi no Grupo Passa-Dois (P-Tr) da Bacia do Paraná. Apreciações ambientais, climáticas, cronológicas e estratigráficas. In: CONGRESSO BRASILEIRO DE PALEONTOLOGIA, 11, 1989. Anais, Curitiba, p. 195-206.

Ramos, B.D. 2009. Materiais de Tetrapoda encontrados na Formação Rio do Rasto (Permiano Superior, Bacia do Paraná): descrição e considerações bioestratigráficas. Graduação em Ciências Biológicas, Universidade Federal do Paraná, Trabalho de Conclusão de Curso, 66 p.

Ramos, B.D. \& Vega, C.S. 2009. Novo material mandibular e fragmentos pós-cranianos de Tetrapoda registrados na Formação Rio do Rasto (Permiano) no Estado do Paraná, Brasil. In: CONGRESSO BRASILEIRO DE PALEONTOLOGIA, 21, 2009. Livro de Resumos, Belém, UFPA, p. 210-210.

Richter, M. \& Langer, M.C. 1998. Fish remains from the Upper Permian Rio do Rasto Formation (Paraná Basin) of southern Brazil. Journal of African Earth Sciences, 27(1):158-159.

Rubidge, B.S. 1995. Biostratigraphy of the Beaufort Group (Karoo Supergroup). Pretoria, Geological Survey of South Africa, South African Committee for Stratigraphy, p. 1-46 (Biostratigraphic Series 1).

Schneider, R.L.; Mühlmann, H.; Tommasi, E.; Medeiros, R.A.; Daemon, R.F. \& Nogueira, A.A. 1974. Revisão bioestratigráfica da Bacia do Paraná. In: CONGRESSO BRASILEIRO DE GEOLOGIA, 28, 1974. Anais, Porto Alegre, SBG, p. 41-65.

Schoch, R. R.1999. Comparative osteology of Mastodonsaurus giganteus (Jaeger, 1828) from the Middle Triassic (Lettenkeuper: Longobardian) of Germany (Baden-Württemberg, Bayern, Thüringen). Stuttgarter Beiträge zur Naturkunde, Serie B, Geologie und Paläontologie, 278:1-175.

Vega, C.S. \& Ramos, B.D. 2008. Mandíbula, materiais pós-cranianos e escamas de Tetrapoda registrados na Formação Rio do Rasto, Permiano da Bacia do Paraná, Brasil. In: CONGRESSO BRASILEIRO DE GEOLOGIA, 44, 2008. Anais, Curitiba, p. 795-795.

Vega-Dias, C.; Dias, E.V. \& Richter, M. 2000. Actinopterygian remains from the Rio do Rasto Formation, Upper Permian of the Paraná Basin, Brazil. Acta Geologica Leopoldensia, 22(51):21-31.

Ventura-Santos, R.; Sousa, P.A.; Alvarenga, C.J.S.; Dantas, E.L.; Pimentel, M.M.; Oliveira, C.G. \& Araújo, L.M. 2006. Shrimp U $\mathrm{Pb}$ zircon dating and palynology of bentonitic layers from the Permian Irati Formation, Paraná Basin, Brazil. Gondwana Research, 9:456-463. doi:10.1016/j.gr.2005.12.001

Witzmann, F. \& Schoch, R.R. 2006. The postcranium of Archegosaurus decheni and a phylogenetic analysis of temnospondyl postcrania. Palaeontology, 49(6):1211-1235. doi: 10.1111/j.1475-4983.2006.00593.x

Received in April, 2010; accepted in February, 2011. 